\title{
A Mineralogical Investigation of Sintering in Cu-Rich Polymetallic Concentrates During Roasting in Inert Atmosphere
}

\begin{abstract}
PANDE NISHANT PRASAD, ANDREAS LENNARTSSON, and CAISA SAMUELSSON
Four different $\mathrm{Cu}$-rich polymetallic concentrates (additionally comprising $\mathrm{Zn}, \mathrm{Pb}$ and impurity elements $\mathrm{As}, \mathrm{Sb}$ ) from various deposits in Sweden are examined, in particular for the sintering tendency during roasting in inert atmosphere. Experiments performed in a laboratory-scale roasting setup between $200{ }^{\circ} \mathrm{C}$ and $700{ }^{\circ} \mathrm{C}$ in intervals of $100{ }^{\circ} \mathrm{C}$ revealed that significant sintering initiates from $500{ }^{\circ} \mathrm{C}$ for all four concentrates. Two sintering mechanisms are determined from the examination of the sintered calcines: (1) solid-state assimilation of $\mathrm{Cu}-, \mathrm{Zn}$ and Fe-bearing main sulphide minerals to form a high-temperature solid solution, the iss phase belonging to the $\mathrm{Cu}-\mathrm{Fe}-\mathrm{Zn}-\mathrm{S}$ system; (2) low-melting liquid phase formation due to partial melting of galena facilitated by the presence of impurity-bearing minerals, mainly the arsenopyrite and $\mathrm{Sb}$ sulphosalts such as tetrahedrite. Galena also forms a melt below $700{ }^{\circ} \mathrm{C}$ with the iss phase. Therefore, the presence of galena in polymetallic concentrates generally increases the susceptibility to early sintering. These experiments in inert atmosphere facilitate a fundamental study with practical relevance to the roasting in low oxidation potential environments, favourable for volatilization of impurity elements such as As and Sb.
\end{abstract}

https://doi.org/10.1007/s11663-020-01850-8

(C) The Author(s) 2020

\section{INTRODUCTION}

CU-RICH polymetallic concentrates most commonly belong to the $\mathrm{Cu}-\mathrm{Fe}-\mathrm{Pb}-\mathrm{Zn}-\mathrm{S}$ system. They can additionally have elements such as $\mathrm{Ag}, \mathrm{Au}, \mathrm{As}, \mathrm{Sb}$ and $\mathrm{Bi}$ in minor quantities. The Group 15 elements such as $\mathrm{As}$ and $\mathrm{Sb}$ are of concern as these impurity elements are difficult to remove in the conventional smelting-converting copper extraction process. The acceptable limits for these elements in the concentrates are generally very low (As $<0.2$ wt pct, Sb-nil), and their concentrations above these limits may lead to smelter penalties. ${ }^{[1]}$

Several experimental investigations have been performed aiming towards volatilization of impurity elements during roasting. Since As and Sb have tendencies to form non-volatile oxides at very low oxidation potential $\left[\mathrm{As}_{2} \mathrm{O}_{4}(\mathrm{~s})\right.$ forms at $\mathrm{p}^{\mathrm{O}_{2}}=10^{-5.35}$ bar and $\mathrm{Sb}_{2} \mathrm{O}_{4}(\mathrm{~s})$ forms at $\mathrm{p}^{\mathrm{O}_{2}}=10^{-10}$ bar, $\left.700{ }^{\circ} \mathrm{C}^{[2]}\right]$, the gas atmosphere during these experiments is maintained at either low oxidation potential ${ }^{[3-6]}$ or inert. ${ }^{[7-10]}$

PANDE NISHANT PRASAD, ANDREAS LENNARTSSON and CAISA SAMUELSSON are with Luleå Tekniska Universitet, 97187 Luleå, Sweden. Contact e-mail: pande.nishant.prasad@ltu.se

Manuscript submitted November 2, 2019.

Article published online May 13, 2020.
Removal efficiency of As has been found to be much better compared with that of $\mathrm{Sb}$ while roasting in inert conditions up to $700{ }^{\circ} \mathrm{C} \cdot .^{[4,9,11]}$ Haga et al. ${ }^{[11]}$ reported that only above $700{ }^{\circ} \mathrm{C}$ did the $\mathrm{Sb}$ volatilization in inert atmosphere improve appreciably and up to $90 \mathrm{pct}$ removal could be achieved at $1200{ }^{\circ} \mathrm{C}$. However, the problem of incipient sintering of the calcines has been frequently reported $\mathrm{d}^{[7,9,10]}$ when the temperature of $700{ }^{\circ} \mathrm{C}$ is approached while heating the polymetallic concentrates in inert atmosphere.

Sintering is therefore a major problem to be resolved for a feasible volatilization of impurity elements during roasting. There have been limited studies related to sintering of concentrates during roasting. With some studies on zinc concentrates during oxidative roasting, ${ }^{[12-14]}$ sintering has been only occasionally discussed for copper-rich concentrates, ${ }^{[10]}$ lacking a detailed mineralogical investigation.

Typical mineral phases in polymetallic sulphide concentrates include sulphides, sulphosalts ${ }^{[4,15-19]}$ and metallic minerals lacking sulphur, e.g., silver antimonides. ${ }^{[16]}$ A list of these minerals and their abbreviations referred to in this article are presented in Table I. Major minerals in the polymetallic concentrates are commonly chalcopyrite, sphalerite, galena and pyrite.

In the context of mineral assemblage and metamorphism in sulphide ore deposits, high-temperature transformations in sulphide systems in inert atmosphere have been widely investigated. Kojima et al. ${ }^{[20,21]}$ determined 
Table I. List of Mineral Abbreviations

\begin{tabular}{lcl}
\hline Mineral & Abbreviation & \multicolumn{1}{c}{ Stoichiometric Formula } \\
\hline Chalcopyrite & $\mathrm{Ccp}$ & $\mathrm{CuFeS}$ \\
Sphalerite & $\mathrm{Sph}$ & $(\mathrm{Zn}, \mathrm{Fe}) \mathrm{S}$ \\
Galena & $\mathrm{Gn}$ & $\mathrm{PbS}$ \\
Pyrite & $\mathrm{Py}$ & $\mathrm{FeS}_{2}$ \\
Pyrrhotite & $\mathrm{Po}$ & $\mathrm{Fe}_{1-\mathrm{x}} \mathrm{S}$ \\
Arsenopyrite & $\mathrm{Asy}$ & $\mathrm{FeAsS}$ \\
Tetrahedrite & $\mathrm{Ttr}$ & $\left(\mathrm{Cu}_{1} \mathrm{Ag}, \mathrm{Fe}, \mathrm{Zn}\right)_{12}(\mathrm{Sb}, \mathrm{As})_{4} \mathrm{~S}_{13}$ \\
Skinnerite & $\mathrm{Skn}$ & $\mathrm{Cu}_{3} \mathrm{SbS}_{3}$ \\
Bournonite & $\mathrm{Bour}$ & $\mathrm{CuPbSbS}_{3}$ \\
Meneghinite & $\mathrm{Mene}$ & $\mathrm{CuPb}_{13} \mathrm{Sb}_{7} \mathrm{~S}_{24}$ \\
Gudmundite & $\mathrm{Gud}$ & $\mathrm{FeSbS}$ \\
Dyscrasite & Dys & $\mathrm{Ag}_{3} \mathrm{Sb}$ \\
\hline
\end{tabular}

the composition fields of solid solutions existing in the $\mathrm{CuS}-\mathrm{ZnS}-\mathrm{FeS}$ system (50 mol pet $\mathrm{S}$ plain of quaternary $\mathrm{Cu}-\mathrm{Fe}-\mathrm{Zn}-\mathrm{S}$ system) to establish the phase relations among chalcopyrite, sphalerite and pyrite in geologically significant temperatures and pressures. Investigations related to melting in sulphide systems ${ }^{[17,22,23]}$ highlighted the role of galena in lowering the melt formation temperatures. According to Tomkins et al. ${ }^{[18]}$ and Pruseth et al., ${ }^{[24]}$ melts can form below $550{ }^{\circ} \mathrm{C}$ if the polymetallic sulphide system additionally comprises minerals such as $\mathrm{Sb}$ sulphosalts.

At a further low temperature of $491{ }^{\circ} \mathrm{C}$ (1 bar), Tomkins et al. ${ }^{[25]}$ suggested that an As-S melt forms because of the breakdown of arsenopyrite minerals occurring in conjunction with the decomposition of pyrite to pyrrhotite. They stated that this As-S melt can be a precursor to melting of other sulphides and sulphosalts at temperatures much below their melting points.

The above-listed studies contributed to the understanding of chemical factors that cause metamorphism and the consequent phase assemblage in sulphide deposits. Conditions of roasting concentrates in inert atmosphere are similar, except that during metamorphism the minerals transform under high pressure. However, the applicability of the geologically relevant high temperature mineralogical relationships during roasting in inert atmosphere has never been explored. The present study is aimed towards determination of the mineral transformations that lead to sintering during inert atmosphere roasting of polymetallic $\mathrm{Cu}$-rich concentrates. Though the roasting in industrial scale is partially oxidative, this work involving experiments in inert atmosphere will be a fundamental study to determine the sintering behaviour in $\mathrm{Cu}$-rich concentrates at high temperature in a low oxidation potential environment, favourable for impurity removal (As and $\mathrm{Sb})$.

Four Cu-rich polymetallic concentrates produced from selected sulphide ore deposits in Sweden bearing impurity elements such as $\mathrm{As}$ and $\mathrm{Sb}$ in high concentrations are used for performing laboratory-scale roasting experiments in this study. Using the high-temperature phase relations available mostly in the geological literature, the mechanisms contributing to sintering will be determined. This investigation will help in the identification of mineral phases that are responsible for the initiation of sintering below the normal roasting temperature of $700{ }^{\circ} \mathrm{C}$.

\section{EXPERIMENTAL DESIGN AND ANALYTI- CAL TECHNIQUES}

\section{A. Materials}

Four $\mathrm{Cu}$-rich polymetallic concentrates belonging to the Rockliden, Maurliden and Garpenberg deposits in Sweden were selected for this study. As shown in Table II, they mainly comprise $\mathrm{Cu}, \mathrm{Zn}, \mathrm{Pb}$ and $\mathrm{Fe}$ in addition to the impurity elements $\mathrm{As}$ and $\mathrm{Sb}$.

The Garpenberg and Maurliden concentrates were obtained from the concentrate production units of Boliden Mineral AB, Sweden. The Rockliden deposit is presently not mined, but ore samples from this deposit were generated by Boliden Mineral AB during previous exploration studies by blasting of the deposit surface and also through drilled cores. ${ }^{[26]}$ The Rockliden 8232 concentrate is from the Copper Cleaner Concentrate $(\mathrm{Cu} \mathrm{CC})$ stream produced in a pilot flotation setup at Boliden Mineral AB by processing surface blasted ore feed (details of the pilot setup mentioned in Lager et al. $\left.{ }^{[19]}\right)$. The Rockliden S7574 concentrate belongs to the $\mathrm{CuCC}$ stream produced during a previous study $[15,27]$ in a laboratory flotation setup using drilled core samples from the depth of 100 to $200 \mathrm{~m}$ in the Rockliden deposit.

The four concentrates were dried in an oven at $105^{\circ} \mathrm{C}$ for 7 days and subsequently screened to obtain a size fraction between 38 and $53 \mu \mathrm{m}$ for each concentrate. This size fraction was used for all characterizations and experiments. The chemical compositions shown in Table II were reported by ALS Scandinavia AB, Luleå, using the method of melting with $\mathrm{LiBO}_{2}$, digestion in $\mathrm{HNO}_{3} / \mathrm{HCl} / \mathrm{HF}$ and measurement using ICP-SFMS in accordance with SS EN ISO 17294-2: 2016 and EPA method 200.8: 1994.

\section{B. Roasting Experimental Setup}

Each of the four concentrates was tested in a vertical tube furnace setup presented schematically in Figure 1. The vertical tube made of alumina has an inner diameter of $85 \mathrm{~mm}$. It can be heated to a desired temperature by Kanthal Super heating elements connected to a controller attached with a thermocouple. The length of the uniform temperature zone in the tube is $10 \mathrm{~cm}$. The gas atmosphere inside the furnace during each run is kept inert by maintaining a flow of nitrogen (Chemical Nitrogen 4.6 from AGA-Linde, purity $\geq 99.996$ pct, $\left.\mathrm{H}_{2} \mathrm{O} \leq 5 \mathrm{ppm}, \mathrm{O}_{2} \leq 5 \mathrm{ppm}\right)$ at $5 \mathrm{1} / \mathrm{min}$. There is a box connected to the lower end of the tube with a front gas-tight door, which is used to introduce the sample inside the furnace. 
Table II. Chemical Composition of Copper Concentrates for the 38 to $53 \mu \mathrm{m}$ Size Fraction

\begin{tabular}{|c|c|c|c|c|}
\hline $\mathrm{Cu}$ Concentrate (Wt Pct) & Rockliden S7574 & Rockliden 8232 & Garpenberg & Maurliden \\
\hline $\mathrm{Cu}$ & 13.8 & 16.6 & 19.3 & 15.4 \\
\hline $\mathrm{Zn}$ & 8.4 & 4.7 & 9.5 & 4.5 \\
\hline $\mathrm{Pb}$ & 5.2 & 5 & 15.3 & 11.3 \\
\hline $\mathrm{Fe}$ & 25.1 & 21.6 & 19.8 & 31.3 \\
\hline $\mathrm{Si}$ & 0.3 & 3.8 & 0.8 & 0.3 \\
\hline $\mathrm{Mg}$ & 0.1 & 2.0 & 0.2 & 0.1 \\
\hline $\mathrm{S}$ & 31.4 & 22.6 & 26.1 & 33.3 \\
\hline $\mathrm{Ag}$ & 0.03 & 0.026 & 1.82 & 0.036 \\
\hline As & 0.74 & 0.44 & 0.23 & 2.1 \\
\hline $\mathrm{Sb}$ & 1.36 & 1.72 & 2.04 & 3.77 \\
\hline
\end{tabular}

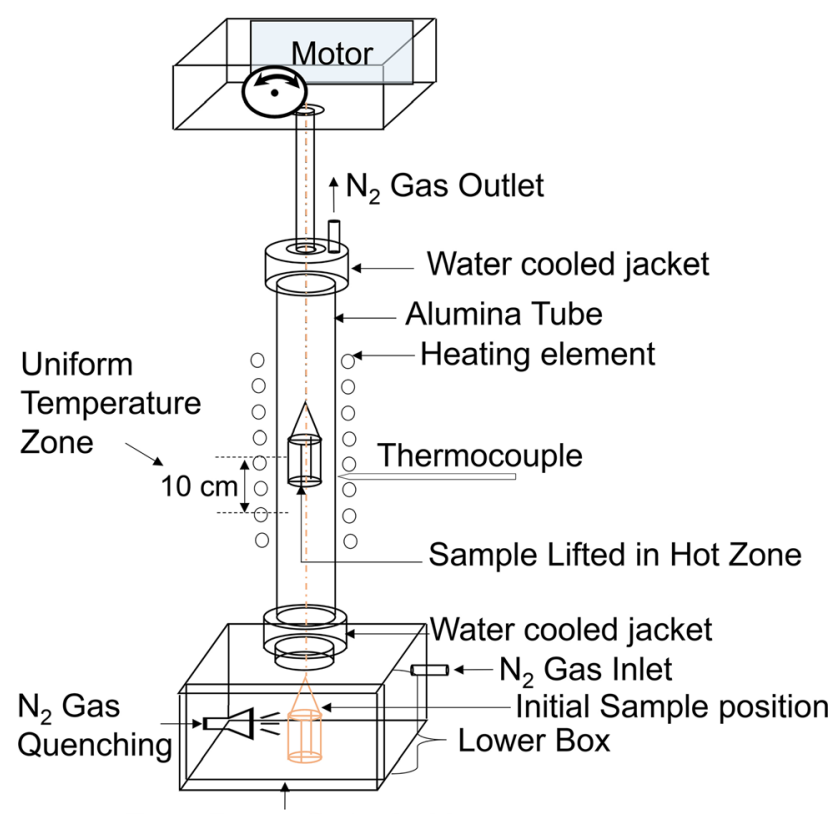

Front Door - Detachable

Fig. 1-Experimental setup for roasting of concentrates.

In an experimental run, $10 \mathrm{~g}$ of the dried concentrate is put in a cylindrical alumina crucible with inner diameter of $36 \mathrm{~mm}$. The crucible is suspended by a chain connected to a motor at the top. After introducing the sample, the gas-tight front door in the lower box is closed to prevent any ingress of air into the furnace. The motor at the top lifts the sample to the hot zone. In experiments planned with fast cooling, the treated hot sample is lowered by the motor in the cold zone inside the lower box. Thereafter, the sample is subjected to fast cooling by directing a flow of nitrogen at $25 \mathrm{~L} / \mathrm{min}$ towards the crucible walls for $15 \mathrm{~min}$.

The temperature at the centre of the furnace will be less than on the heated walls. An experiment was performed to measure the centre temperature simultaneously with the wall temperature in every 1-s interval while heating the furnace at $4{ }^{\circ} \mathrm{C} / \mathrm{min}$ up to $700{ }^{\circ} \mathrm{C}$ under nitrogen flow, but without any sample charging.

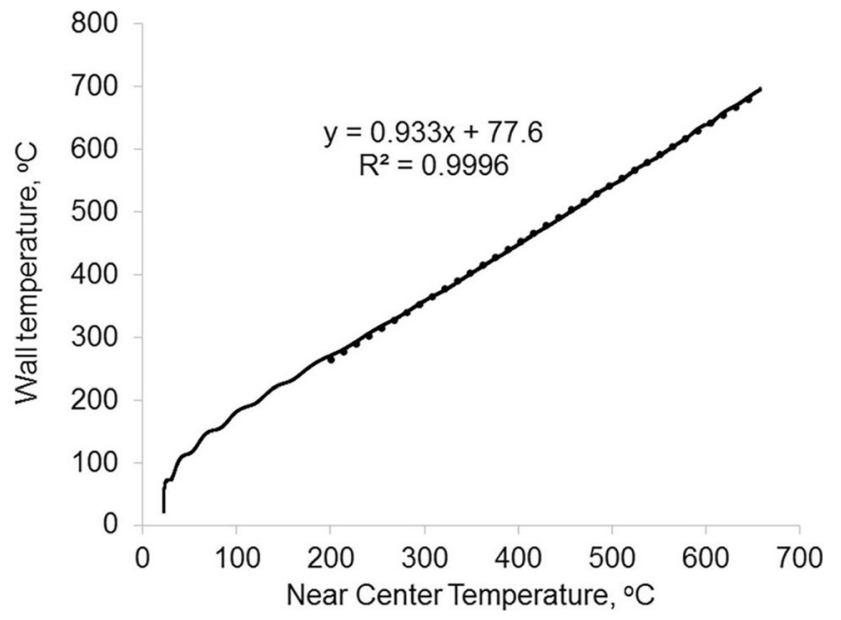

Fig. 2-Relationship between the wall and centre temperatures in the vertical tube furnace.

The centre temperature was measured by an additional thermocouple, introduced through an opening in the top water-cooling jacket nearly along the axis of the furnace (near centre) with its tip mid-way in the vertical uniform temperature zone. Figure 2 shows the linear relationship obtained between the centre temperature $\left(>200{ }^{\circ} \mathrm{C}\right)$ and the wall temperature.

This relationship was used in actual roasting experiments to fix the wall temperature set points for attaining a desired sample temperature.

Two types of experiments were performed using the above setup:

(a) Isothermal roasting: The sample was kept waiting in inert conditions at room temperature inside the lower box until the desired temperature was achieved in the furnace. On attainment of the desired furnace temperature, the sample was lifted by the motor, placed inside the uniform temperature zone and held there for $70 \mathrm{~min}$. Thereafter, the sample was lowered and subjected to fast cooling with nitrogen in the lower box. The chosen isothermal experimental temperatures for different runs were: $200{ }^{\circ} \mathrm{C}, 300{ }^{\circ} \mathrm{C}, 400{ }^{\circ} \mathrm{C}, 500{ }^{\circ} \mathrm{C}, 600^{\circ} \mathrm{C}$ 
and $700{ }^{\circ} \mathrm{C}$. Corresponding set points for the furnace wall temperature according to Figure 2 were $264{ }^{\circ} \mathrm{C}, 357{ }^{\circ} \mathrm{C}, 451{ }^{\circ} \mathrm{C}, 544{ }^{\circ} \mathrm{C}, 637{ }^{\circ} \mathrm{C}$ and $731{ }^{\circ} \mathrm{C}$, respectively.

(b) Non-isothermal roasting: In one of the roasting experiments, the charged Garpenberg concentrate was subjected to the same heating and cooling cycles as the furnace. From the beginning, the sample was placed in the uniform temperature zone when the furnace started to heat up at $4^{\circ} \mathrm{C} / \mathrm{min}$ from room temperature. On attainment of $731{ }^{\circ} \mathrm{C}$ (centre temperature $\approx 700{ }^{\circ} \mathrm{C}$ ), the temperature was maintained constant for $60 \mathrm{~min}$. Subsequently, the furnace was cooled down at $3{ }^{\circ} \mathrm{C} / \mathrm{min}$ while the sample remained in the uniform temperature zone (hot zone). The treated sample was lowered and withdrawn after the furnace cooled down to room temperature.

\section{SEM/EDS Analysis}

The initial concentrates and calcines obtained from different temperature runs (both isothermal and non-isothermal) were mounted in epoxy, polished and carbon coated. They were examined under a Zeiss Merlin FEG SEM (scanning electron microscope) and analysed using an Oxford Instruments X-Max EDS (energy-dispersive X-ray spectroscopy) detector operated by AZtec software. The beam measurement during EDS analyses was calibrated using pure copper. The elemental composition obtained from EDS measurements is reported in mol pet and normalized so that the summation for all identified elements is 100 mol pet.

\section{Powder XRD}

Powder XRD measurements were performed on the initial concentrates and the calcined products from isothermal roasting at different temperatures. The PANalytical Empyrean X-ray diffractometer in $\theta-\theta$ geometry was used for the measurement with $\mathrm{Cu}$ $\mathrm{K} \alpha$ radiation $(\lambda=0.154184 \mathrm{~nm})$, beam current of 40 $\mathrm{mA}$ and beam voltage of $45 \mathrm{mV}$. The XRD pattern was measured in the range of $20 \mathrm{deg} \leq 2 \theta \leq 90 \mathrm{deg}$ with a step size of $0.026 \mathrm{deg} / \mathrm{s}$. A curved graphite crystal monochromator mounted before a PIXcel 3D-detector was used to take care of the fluorescence due to the presence of $\mathrm{Fe}$ in the samples. The measured data were evaluated for phase identification using HighScore Plus (v4.7, PANalytical B.V., Almelo, The Netherlands) software and FIZ-NIST ICSD (Inorganic Crystal Structure Database) database, version 2015-1.

\section{RESULTS AND DISCUSSION}

\section{A. Macroscopic Observation of Early Sintering}

Figure 3 shows the calcined residues of the four concentrates obtained from isothermal roasting at different temperatures.
All four concentrates experienced severe sintering, which was initiated well below $700{ }^{\circ} \mathrm{C}$. The Maurliden concentrate was earliest to sinter, as its particles were slightly agglomerated even at $400{ }^{\circ} \mathrm{C}$. The Garpenberg and Rockliden 8232 concentrates suffered partial sintering from $500{ }^{\circ} \mathrm{C}$, whereas the Rockliden S7574 and Maurliden concentrates were almost fully sintered at $500{ }^{\circ} \mathrm{C}$. Based on these macroscopic observations, the four concentrates can be put in the order of increasing sintering susceptibility as below:

$$
\begin{aligned}
& \text { Early Sintering Susceptibility: Rockliden } 8232 \\
& <\text { Garpenberg }<\text { RocklidenS7574 }<\text { Maurliden }
\end{aligned}
$$

\section{B. Initial Mineralogy and Transformations Determined by $X R D$}

Figure 4 presents the XRD patterns for the starting concentrates and their respective calcines obtained from isothermal roasting at different temperatures.

The principal $\mathrm{Cu}-, \mathrm{Pb}$ - and $\mathrm{Zn}$-bearing phases in all four concentrates are $\mathrm{Ccp}, \mathrm{Gn}$ and $\mathrm{Sph}$, respectively. Also, Py is the phase comprising the excess Fe. In Table III, the quantity of these main minerals in the concentrates are estimated using the chemical compositions listed in Table II.

The proportion of $\mathrm{Py}$ is comparatively low in the Garpenberg concentrate (Table III). It also goes undetected during XRD measurement of this concentrate (peaks for Py missing in Figure 4(c)).

At high temperature, the peaks for Py in the other three concentrates progressively diminish (Figures 4(a), (b) and (d)), suggesting its decomposition to form Po.

In addition, the closely located 100 pct intensity peaks for both $\mathrm{Ccp}$ and $\mathrm{Sph}$ at $2 \theta \approx 29 \mathrm{deg}$ tend to broaden, indicating an eventual merger with a rise in temperature. Also, the intensity of the peaks for $\mathrm{Sph}$ reduces significantly, as shown in Figures 4(a), (b) and (d). An explanation for this merger of Ccp and Sph peaks, and diminution of $\mathrm{Sph}$ peaks at high temperature, comes later in this article.

\section{Microscopic Observations and Measurements Using $S E M / E D S$}

\section{Initial mineralogy of impurity elements in concentrates}

A simple quantitative assessment of minerals bearing impurity elements As and $\mathrm{Sb}$ was performed based on numerous EDS measurements on epoxy grain mounts of the concentrates. A count of the number of times the EDS compositions conformed closely to a specific mineral was determined. More than 100 such EDS measurements were performed at randomly located spots in frames of $400 \times$ magnification. $N_{\text {EDS }}$, the number of counts of encountering a mineral per 100 spot measurements, is presented in Figure 5.

On the basis of $N_{\text {EDS }}$, occurrence of a minor mineral in a concentrate is regarded as 'P-Present' $\left(N_{\mathrm{EDS}}>4\right)$, R-Rare' $\left(N_{\mathrm{EDS}} \leq 4\right)$ or 'NP-Not Present' $\left(N_{\mathrm{EDS}}=0\right)$ as listed in Table IV. 


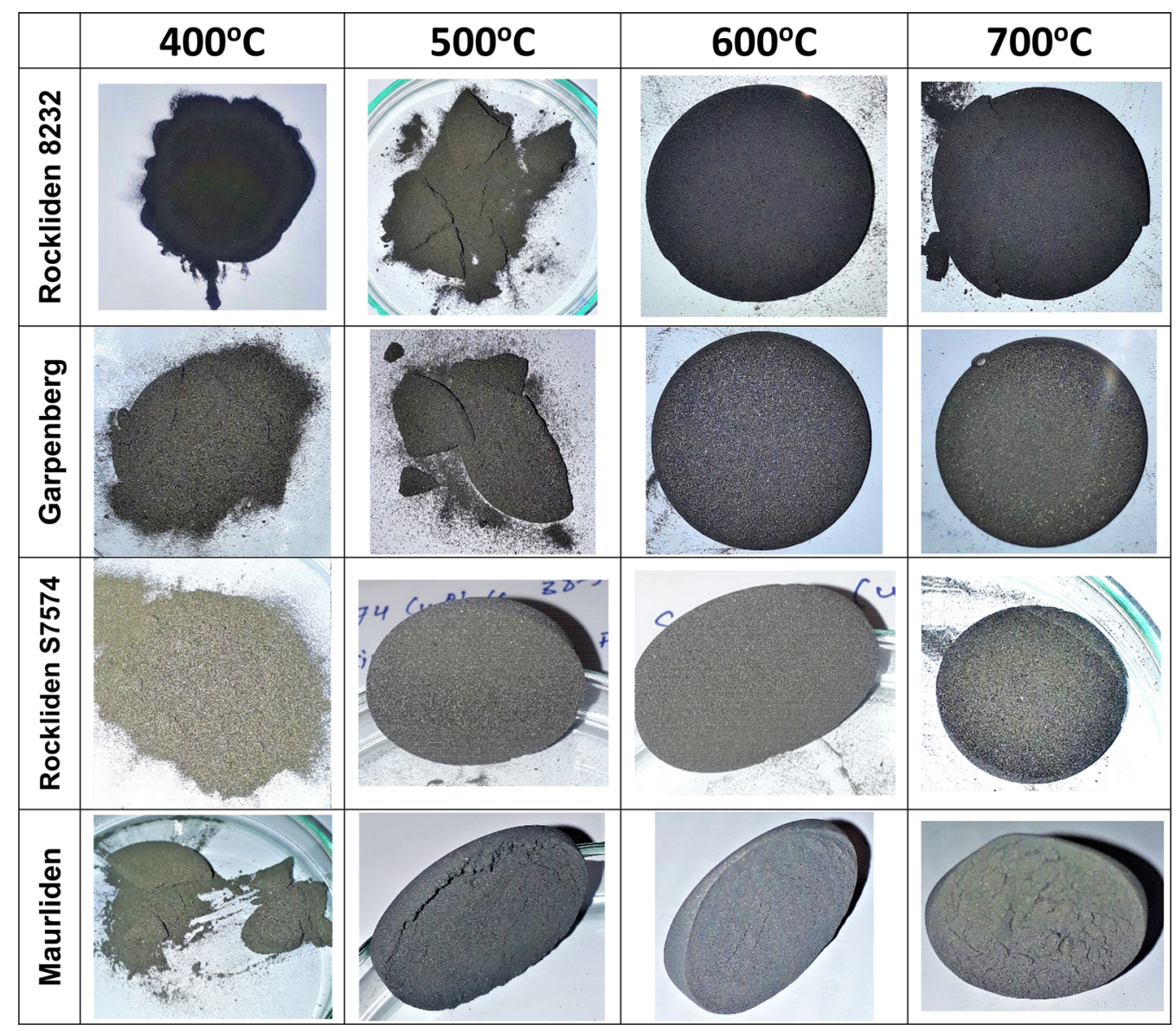

Fig. 3-Appearance of the calcines produced by isothermal roasting of $10 \mathrm{~g}$ of concentrates (38 to $53 \mu \mathrm{m}$ size fraction) at different temperatures.

Notably, Ttr is present in all the concentrates as the main Sb mineral. Similarly, Asy is the main As-bearing mineral in the four concentrates. It is however found only a few times during EDS measurements on Rockliden 8232 and Garpenberg concentrates as they are relatively low in As content (Table II).

\section{Microscopic evaluation of the sintering phenomenon}

Microscopic study in SEM revealed that there were two modes of particle agglomeration leading to the sintering of calcines in all the four concentrates during roasting experiments:

(1) Sintering due to assimilation of minerals in solid state

(2) Sintering due to liquid phase formation

The evidence for the above listed mechanisms of sintering is presented here.

a. Sintering due to solid-state assimilation An example of sintering due to solid-state assimilation is presented in Figure 6, which comprises the SEM analyses of the calcine obtained by isothermal roasting of Rockliden S7574 concentrate at $600{ }^{\circ} \mathrm{C}$. In the BSE (back-scattered electron) image in Figure 6(a), different mineral particles (recognized by dissimilar grey levels) appear to start merging with each other.
The elemental mapping shown in Figures 6(b) through (e) delineates the chemical distinction of the mineral phases undergoing this solid-state assimilation. The slightly S-rich phase shown in the S map (bright green areas in Figure 6(b), corresponding dark grey areas in the BSE image in Figure 6(a)) also comprises Fe (Figure 6(c)), but lacks Cu (Figure 6(d)) and Zn (Figure 6(e)). Due to its higher sulphur content compared with other sulphide phases, it is clearly the Po $\left(\mathrm{Fe}_{1-x} \mathrm{~S}\right)$ phase (originally Py).

Besides Po, there are the $\mathrm{Cu}$-rich (dense blue areas in Figure 6(d)) and Zn-rich (dense blue areas in Figure 6(e)) sulphide phases that also participated in the solid-state assimilation.

The thermodynamic basis of the solid-state assimilation observed in the present study can be found in the work of Kojima et al. ${ }^{[20,21]}$ They stated that two solid solutions exist in the ternary CuS-ZnS-FeS system: the $\mathrm{Cu}$-rich iss phase (intermediate solid solution) and the Zn-rich Sph-ss phase (sphalerite solid solution). With an increase in temperature, the iss-phase boundary expands towards more $\mathrm{Zn}$ mol pet and Fe mol pct. Simultaneously, the Sph-ss phase expands towards more $\mathrm{Cu}$ mol pct and Fe mol pct. Therefore, when the polymetallic concentrates are heated in inert atmosphere, the $\mathrm{Cu}$ - and Zn-rich minerals (Ccp and $\mathrm{Sph}$ respectively in the present concentrates) tend to inter-assimilate along the 
Rockliden S7574

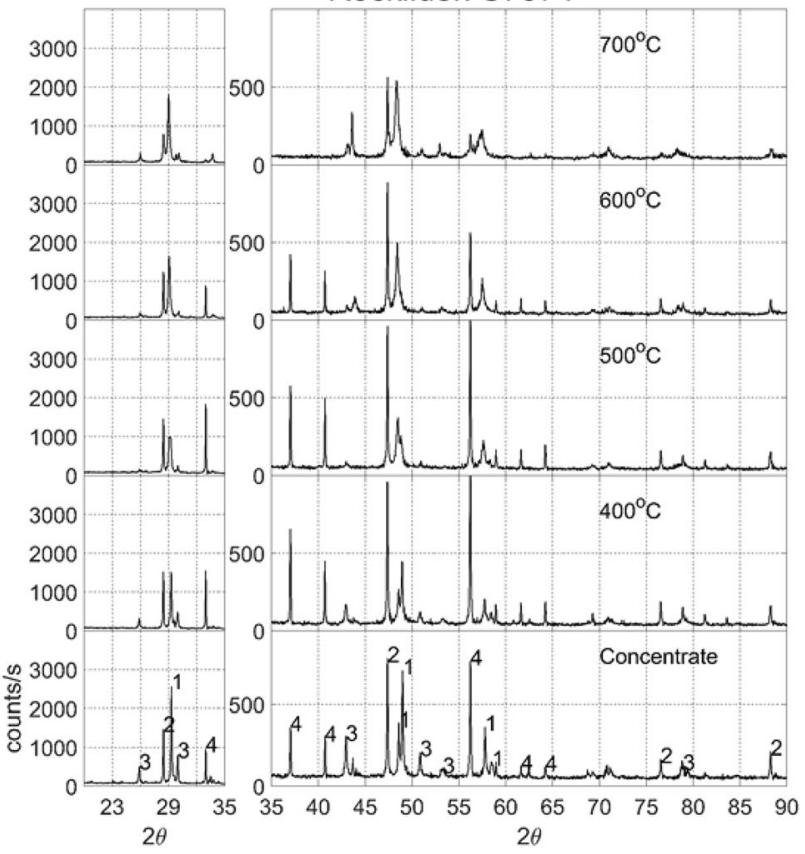

(a)

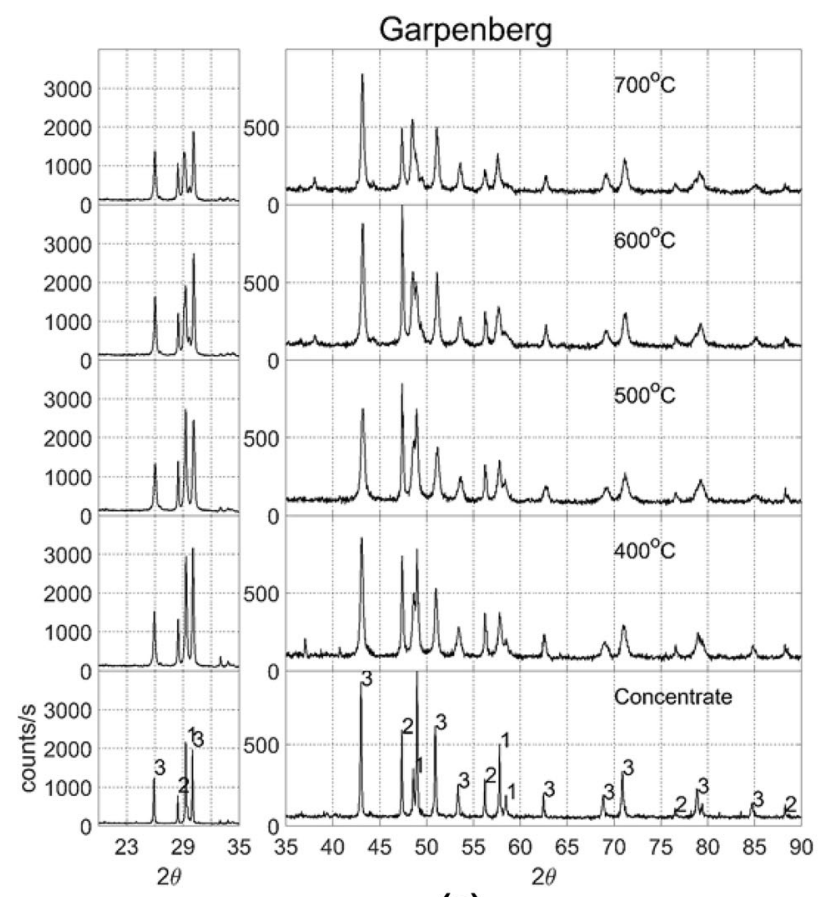

(c)

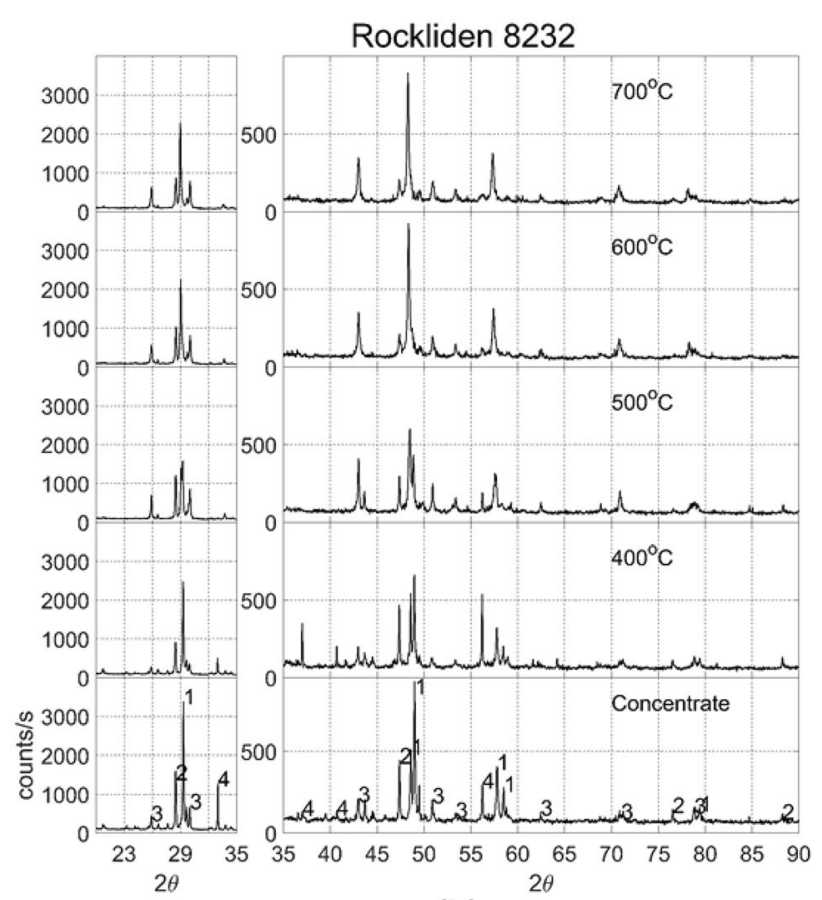

(b)

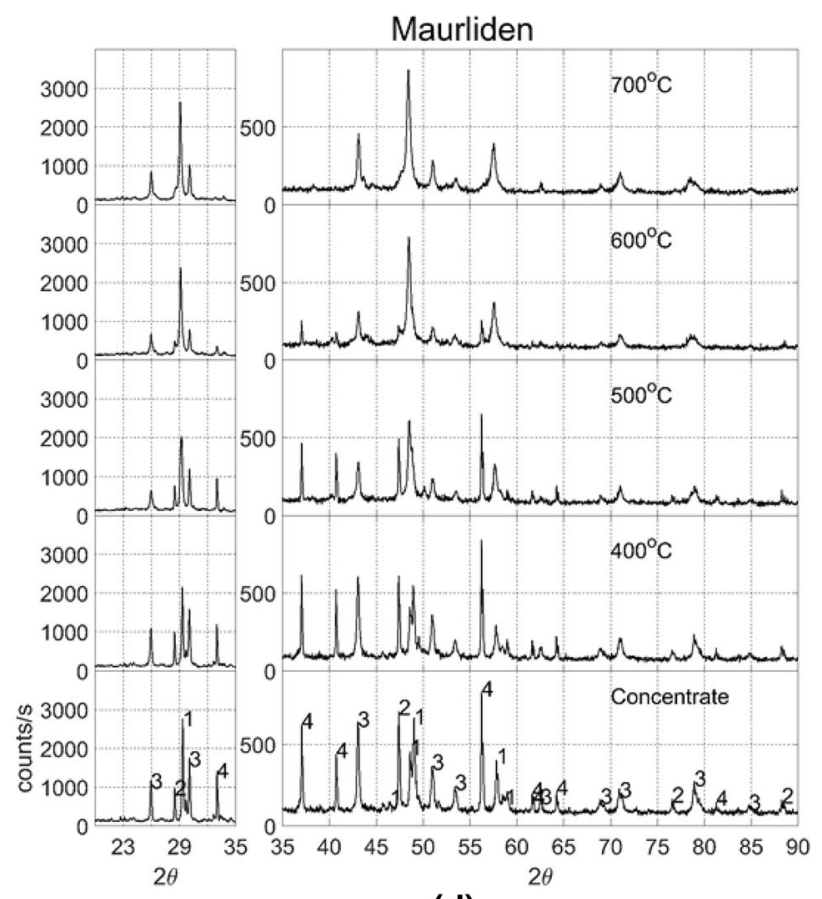

(d)

\begin{tabular}{|c|c|c|c|c|}
\hline Peak ID & 1 & 2 & 3 & 4 \\
\hline Mineral & Ccp & Sph & Gn & Py \\
\hline $\mathbf{2 0}^{100 \%}$ & $29.37^{\circ}$ & $28.49^{\circ}$ & $30.06^{\circ}$ & $56.27^{\circ}$ \\
\hline
\end{tabular}

(e)

Fig. 4-XRD patterns for the concentrates and calcines obtained from isothermal roasting for (a) Rockliden S7574; (b) Rockliden 8232; (c) Garpenberg; $(d)$ Maurliden; $(e)$ Tabulated Peak ID and mineral details. $2 \theta^{100}$ pct is the maximum intensity position of the corresponding mineral. Note: For clear visualization of relatively short peaks, each XRD pattern is plotted into two segments: $2 \theta=20$ to 35 deg and $2 \theta=35$ to 90 deg with $Y$ axis ranges 0 to 4000 counts/s and 0 to 1000 counts/s, respectively. 
Table III. Major Mineral Composition in Concentrates Before Roasting, Estimated Using XRD and the Chemical Composition; Based on EDS Measurements, the Chemical Formulae for Ccp, Gn and Py Are Considered Theoretical; Formulae for Sph Are Derived from EDS

\begin{tabular}{lcccr}
\hline & \multicolumn{3}{c}{ Major Mineral Composition } \\
\cline { 2 - 5 } Concentrates & Ccp (Weight Pct) & Sph (Weight Pct) & Gn (Weight Pct) & Py (Weight Pct) \\
\hline Rockliden S7574 & 39.9 & 14.1 & 6.0 & 25.6 \\
Rockliden 8232 & 48.0 & 7.8 & 17.7 & 13.8 \\
Garpenberg & 55.8 & 15.7 & 13.0 & 3.8 \\
Maurliden & 44.5 & 7.3 & 37.2 \\
\hline
\end{tabular}

${ }^{\mathrm{a}}$ The formulae derived for sphalerite for the concentrates were $\mathrm{Zn}_{0.88} \mathrm{Fe}_{0.12} \mathrm{~S}$ for Rockliden $\mathrm{S} 7574 ; \mathrm{Zn}_{0.89} \mathrm{Fe}_{0.11} \mathrm{~S}$ for Rockliden $8232 ; \mathrm{Zn}_{0.89} \mathrm{Fe}_{0.11} \mathrm{~S}$ for Garpenberg; $\mathrm{Zn}_{0.91} \mathrm{Fe}_{0.09} \mathrm{~S}$ for Maurliden.

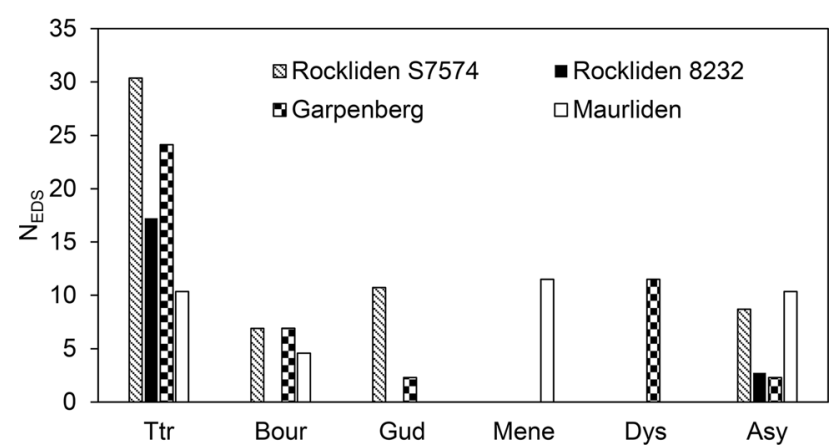

Fig. 5-Number of times the mineral is encountered in every 100 EDS spot measurements, $\mathrm{N}_{\mathrm{EDS}}$.

contact interfaces. The Fe-bearing phases such as Po also participate in these assimilations, providing Fe to these solid solutions as they have increased Fe-saturation limits at high temperature.

Eventually, these inter-assimilations cause dominance of one solid solution and extinction of the other, depending on the $\mathrm{Cu} / \mathrm{Zn}$ molar ratio of the chemical system in consideration. In the present study involving $\mathrm{Cu}$-rich concentrates, the $\mathrm{Cu} / \mathrm{Zn}$ molar ratios are high, which allows the iss phase to dominate and Sph-ss phase to be extinguished. This explains the diminution of the Sph peaks and their merger with the Ccp peaks at high temperature in the XRD patterns shown in Figure 4.

Later in this article, results of the measurement of iss-phase compositions in the calcined residues of the four concentrates corresponding to different roasting temperatures will be presented. The isotherms obtained from Kojima et al.${ }^{[20]}$ shown in Figure 7 will be used to evaluate these compositions to further establish the iss-phase formation as the cause of solid-state assimilations leading to sintering at high temperature.

b. Sintering due to liquid phase formation An illustration of another mechanism of sintering found in this study is shown in Figure 8. The Garpenberg concentrate agglomerates at $500{ }^{\circ} \mathrm{C}$, primarily because of formation of sulphide melts identifiable by their typical myrmekitic texture. This texture typically corresponds to sulphide melts, which do not quench to glass on solidification. ${ }^{[28]}$ The unmelted charge in contact with the melt starts to undergo solid-state recrystallization, which is proven by the occurrence of a polygonal texture surrounded by the intergrown melt phase, similar to the observations made by Stevens et al. ${ }^{[23]}$ during the microscopic study of run products obtained from partial melting of sulphides.

A detailed analysis of the composition of the liquid phases, identification of minerals contributing to their formation and the underlying thermodynamic will be presented later in this article.

3. Composition measurements of the ISS phase formed because of solid-state assimilation

Compositional variation of the iss phase contributing to sintering due to solid-state assimilation in the calcined residues of isothermal roasting at different temperatures was determined from the numerous EDS measurements. Based on the compositional limits of the iss phase shown in Figure 7, all compositions conforming to $5 \mathrm{~mol}$ pct $<$ $\mathrm{Cu}<30$ mol pct together with $20 \mathrm{~mol}$ pct $<\mathrm{Fe}<45 \mathrm{~mol}$ pct and balance $\mathrm{S}+\mathrm{Zn}$ were accepted as the iss phase. Figure 9 presents a box plot showing the variation in sulphur composition in mol pet for all the identified compositions of iss phase.

Clearly, the iss phase has $\mathrm{S} \approx 50 \mathrm{~mol}$ pct at all temperatures (within $\pm 2 \mathrm{~mol} \mathrm{pct}$ ), indicating a sulphur to cation molar ratio of $\mathrm{S} /(\mathrm{Cu}+\mathrm{Fe}+\mathrm{Zn}) \approx 1$. Therefore, the composition values of iss phase determined by EDS measurements can be plotted in a CuS-FeS-ZnS ternary diagram with minor errors. Accordingly, fixing $S$ $=50 \mathrm{~mol}$ pct, the concentrations of the metallic elements $(\mathrm{Cu}, \mathrm{Fe}, \mathrm{Zn})$ in the measured iss-phase compositions were slightly adjusted using Eq. [1], and their ternary plots shown in Figure 10 were generated.

$$
[\mathrm{M}]_{\text {adjusted }}^{\text {mol.pct }}=[\mathrm{M}]_{\text {measured }}^{\text {mol.pct }}\left(1-\frac{50-[S]_{\text {measured }}^{\text {mol.pct }}}{\sum_{\mathrm{M}=\mathrm{Cu}, \mathrm{Fe}, \mathrm{Zn}}[\mathrm{M}]_{\text {measured }}^{\text {mol.pt }}}\right)
$$

Equilibrium phase boundaries of the iss phase from Kojima et al. ${ }^{[20]}$ (shown in Figure 7) are superimposed on these ternary composition plots. Additionally, for each concentrate, two calculated iss compositions are plotted based on the assumed scenarios that because of solid-state assimilation the initial $\mathrm{Ccp}$ at high temperature picks up: (1) all $\mathrm{Fe}$ in the concentrate (green squares) and (2) all $\mathrm{Fe}+\mathrm{Zn}$ in the concentrate (red 
Table IV. Occurrence of Minor Minerals Based on $\mathrm{N}_{\text {EDS }}$, the Number of Times a Mineral Was Encountered per 100 Spots During EDS Measurements: P-Present $\left(N_{\text {EDS }}>4\right)$, R-Rare $\left(N_{\text {EDS }} \leq 4\right)$, NP $\left(N_{\text {EDS }}=0\right)$

\begin{tabular}{lllllcc}
\hline & \multicolumn{5}{c}{ Occurrence of Minor Minerals (P-Present/R-Rare/NP) } \\
\cline { 2 - 6 } Concentrates & Ttr & Bour & Gud & Mene & Dys & Asy \\
\hline Rockliden S7574 & $\mathrm{P}$ & $\mathrm{P}$ & $\mathrm{P}$ & $\mathrm{NP}$ & $\mathrm{P}$ \\
Rockliden 8232 & $\mathrm{P}$ & $\mathrm{NP}$ & $\mathrm{NP}$ & $\mathrm{NP}$ & $\mathrm{R}$ \\
Garpenberg & $\mathrm{P}$ & $\mathrm{P}$ & $\mathrm{R}$ & $\mathrm{P}$ & $\mathrm{NP}$ \\
Maurliden & $\mathrm{P}$ & $\mathrm{P}$ & $\mathrm{NP}$ & $\mathrm{P}$ \\
\hline
\end{tabular}

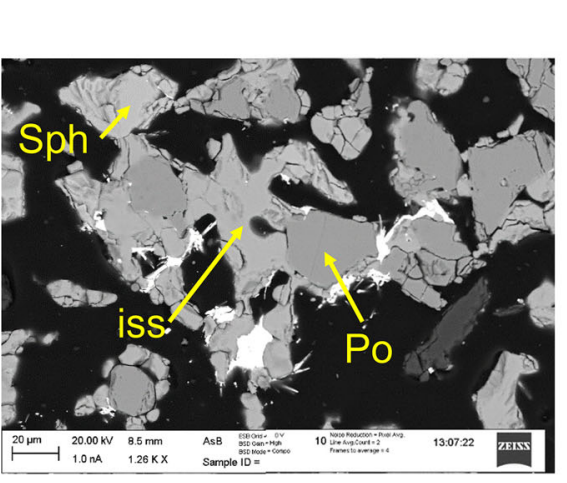

(a)

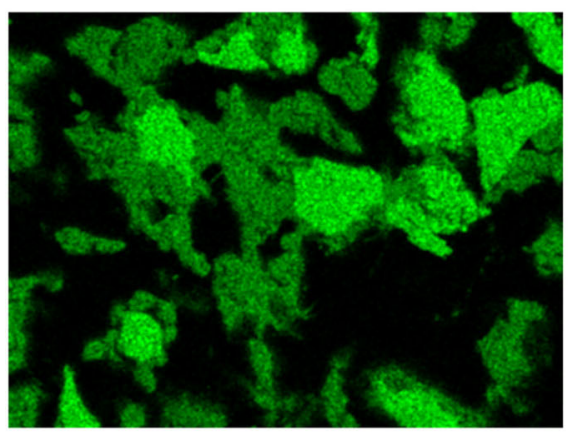

(b)

$$
\text { Cu Ka1 } \longdiv { 5 0 \mu m }
$$

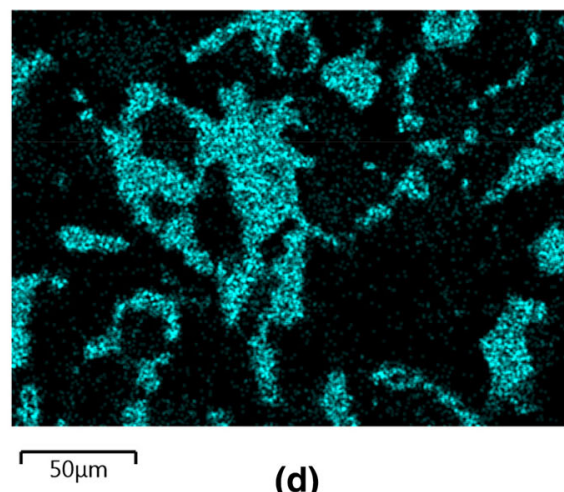

$S K \alpha 1$

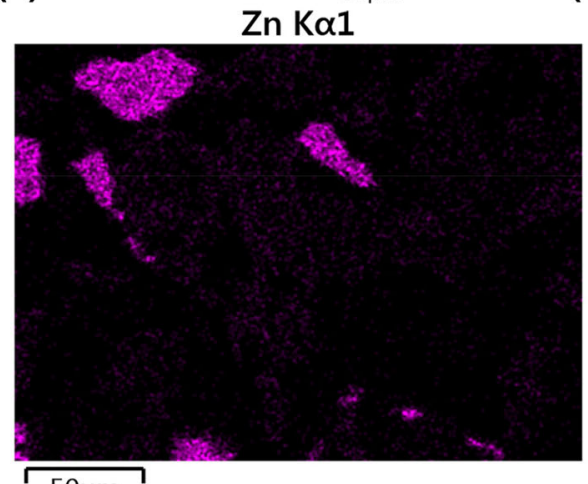

(e)

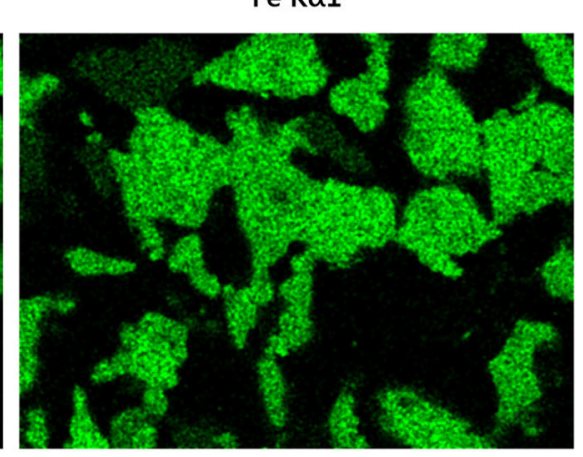

(c)

Fig. 6- $(a)$ BSE image of calcine obtained from isothermal roasting of Rockliden S7574 concentrate (i
Individual maps are presented for the major elements detected: $(b)$ sulphur; $(c)$ iron; $(d)$ copper and $(e)$ zinc.

squares). These compositions are calculated from the elemental composition data of the concentrates presented in Table II.

The measured compositions of Ccp at room temperature (shown as open circles in Figures 10(a) through (d)) in the concentrates are found to be close to the theoretical formula $(50 \mathrm{~mol}$ pct $\mathrm{CuS}, 50 \mathrm{~mol}$ pct FeS) in all the four concentrates. The corresponding high temperature iss phase gains more $\mathrm{Fe}$ and $\mathrm{Zn}$.

Since the system of reacting solid particles in the calcine is extremely heterogeneous, the measured iss-phase compositions vary significantly, noted from the scatter in compositions at any given temperature. Nonetheless, these compositions are found to strictly adhere to the saturation limits set by the phase boundary isotherms, with only a few outliers. For example, the measured compositions in calcines corresponding to the experiment at $700{ }^{\circ} \mathrm{C}$ for Rockliden S7574 concentrate are located along the $700{ }^{\circ} \mathrm{C}$ isotherm (Figure 10(a)).

Second, the measurements that are found to be near the saturation limits at the highest temperature of $700{ }^{\circ} \mathrm{C}$ are in the vicinity of the calculated composition of all $\mathrm{Fe}+\mathrm{Zn}$ assimilations in the initial $\mathrm{Ccp}$ (red squares). This composition is widely distinct for the four concentrates. For instance, for Garpenberg the concentrate it is located at the lowest FeS content amongst all four concentrates (Figure 10(c)) because of its relatively 


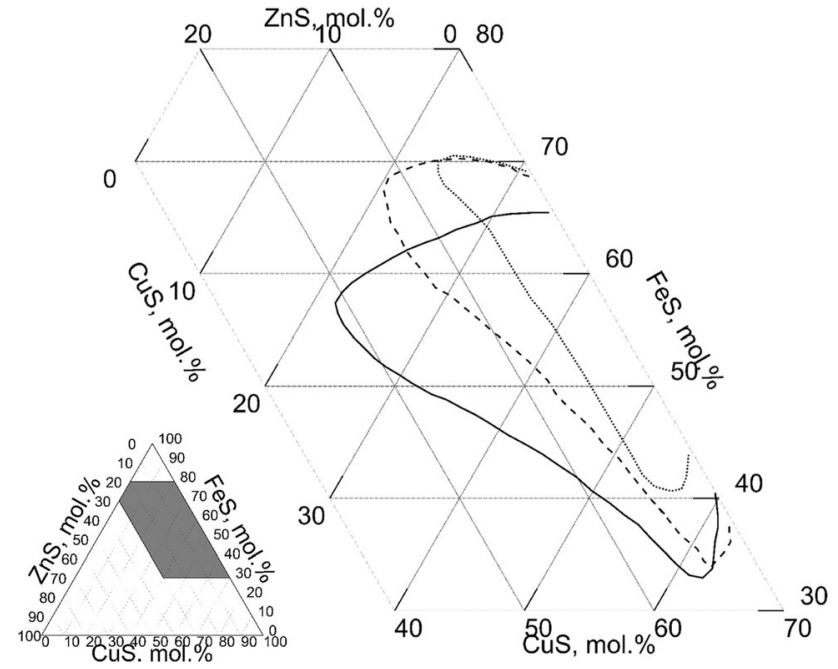

Fig. 7-Phase boundaries of iss phase. Compositions in mol pct. Inset on bottom left delineating the area of the CuS-FeS-ZnS ternary diagram presented in enlarged view. Data from Kojima et al. ${ }^{[20]}$

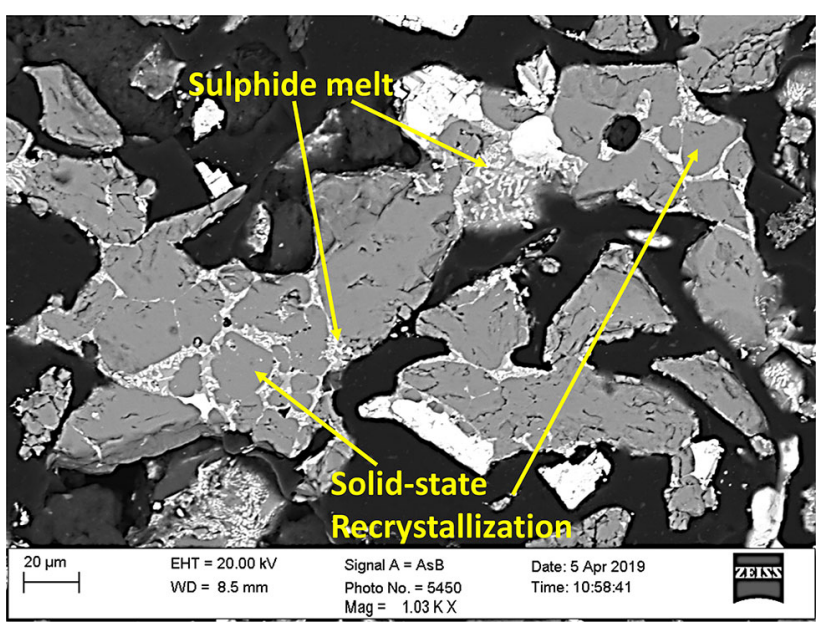

Fig. 8-BSE image of calcine obtained from isothermal roasting of Garpenberg concentrate (initial size 38 to $53 \mu \mathrm{m}$ ) at $500^{\circ} \mathrm{C}$. Myrmekitic intergrowths indicate liquid formation, and polygonal texture represents solid-state recrystallization of the unmelted charge in contact with the melt.

low Fe wt pet (Table I). Similarly, for Maurliden concentrate, it is at the lowest $\mathrm{ZnS}$ content (Figure 10(d)).

Therefore, sintering by solid-state assimilation is driven by the tendency of the initial $\mathrm{Cu}-, \mathrm{Zn}-$ and Fe-bearing sulphide minerals in the concentrate to combine and form a single high-temperature solid solution, the iss phase in the CuS-FeS-ZnS system.

\section{Composition of low melting liquid phases}

Figures 11(a) through (d) presents the BSE images comprising the characteristic texture of liquid phase in the calcines obtained by isothermal roasting at $500{ }^{\circ} \mathrm{C}$ for the four concentrates. EDS measurements were

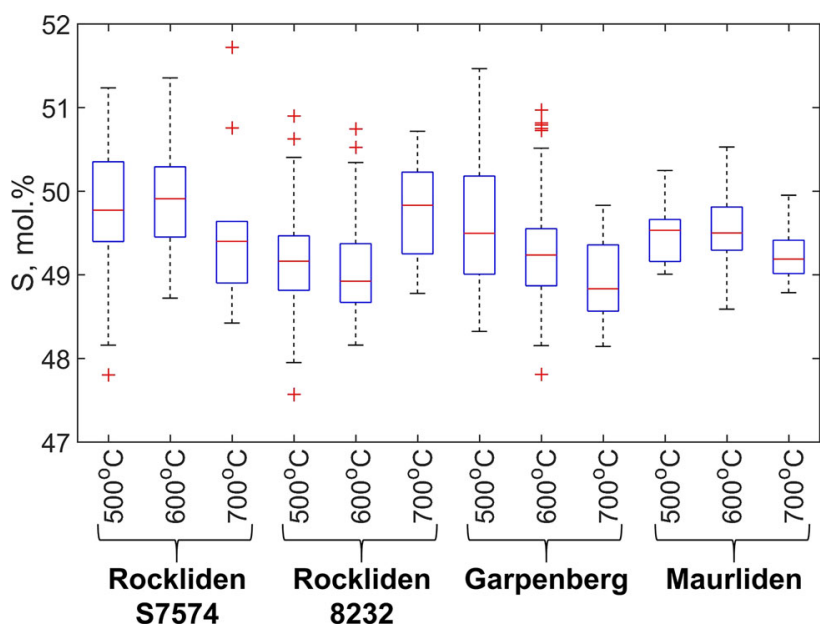

Fig. 9-Box plot of the $\mathrm{S}$ content (mol pct) in iss phase present in calcines obtained from isothermal roasting of the four concentrates at different temperatures. Outliers are plotted as $(+)$.

performed at the indicated spots (repeated measurements of 5 times at each spot) to determine the elemental composition of these liquids.

It is evident in these microscopic images that all four concentrates experienced melt formations during roasting at $500{ }^{\circ} \mathrm{C}$. The melts for Rockliden S7574 and Maurliden concentrates solidified in a single phase (Figures 11(a) and (d), respectively), whereas the melts for Rockliden 8232 and Garpenberg concentrates developed two-phase intergrowth textures on solidification (Figures 11(b) and (c), respectively).

Results of the EDS measurements at selected spots shown in Figure 11 to determine the elemental composition of these liquid-forming phases at $500{ }^{\circ} \mathrm{C}$ are listed in Table V.

Compositions of the solidified single phase in Rockliden S7574 and Maurliden calcines presented in Table $\mathrm{V}$ suggest that the melt formation is due to partial melting of $\mathrm{Gn}$. While $\mathrm{S} \approx 50 \mathrm{~mol}$ pct, $\mathrm{Pb}$ is partly substituted by $\mathrm{As}, \mathrm{Sb}, \mathrm{Fe}$ and $\mathrm{Cu}$. Gn in its pure form melts at $1117{ }^{\circ} \mathrm{C}$. High concentrations of $\mathrm{As}$ and $\mathrm{Sb}$ indicate that impurity-bearing minerals had a major role in partial melting of Gn. As presented in Table IV and Figure 5, Rockliden S7574 and Maurliden concentrates have Asy as the main As-bearing mineral, which is a rare mineral in the Rockliden 8232 and Garpenberg concentrates. Tomkins et al. ${ }^{[25]}$ highlighted Asy as a melt-forming precursor, since it forms a melt phase $\left(A s-\mathrm{S}_{\text {melt }}\right)$ at a low temperature of $491{ }^{\circ} \mathrm{C}(1 \mathrm{bar})$ during the decomposition of Py to Po. They suggested that this liquid phase has a tendency to partially melt sulphides at temperatures much below their melting points, and in this process, a variety of elements, especially the low-melting chalcophile elements (LCME) ${ }^{[17]}$ such as $\mathrm{Pb}, \mathrm{Zn}, \mathrm{Sb}, \mathrm{Ag}$ and $\mathrm{Au}$ can join the As- $\mathrm{S}_{\text {melt }}$ phase. High As content along with other elements in the partially melted Gn found in the present study (Table V) affirms the vitality of Asy as a melt-forming precursor in polymetallic concentrates. Such melts are therefore expected to form in concentrates comprising $\mathrm{Gn}+\mathrm{Py}+$ Asy (in addition 


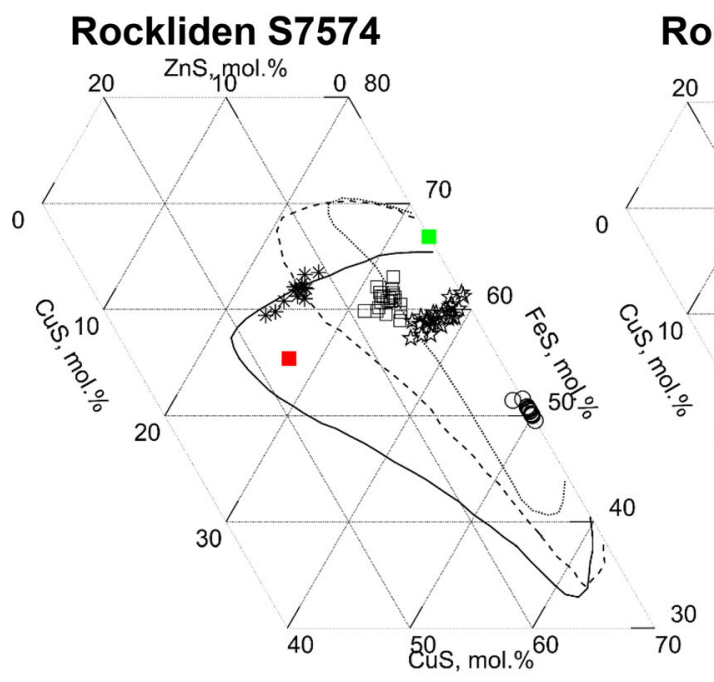

(a)

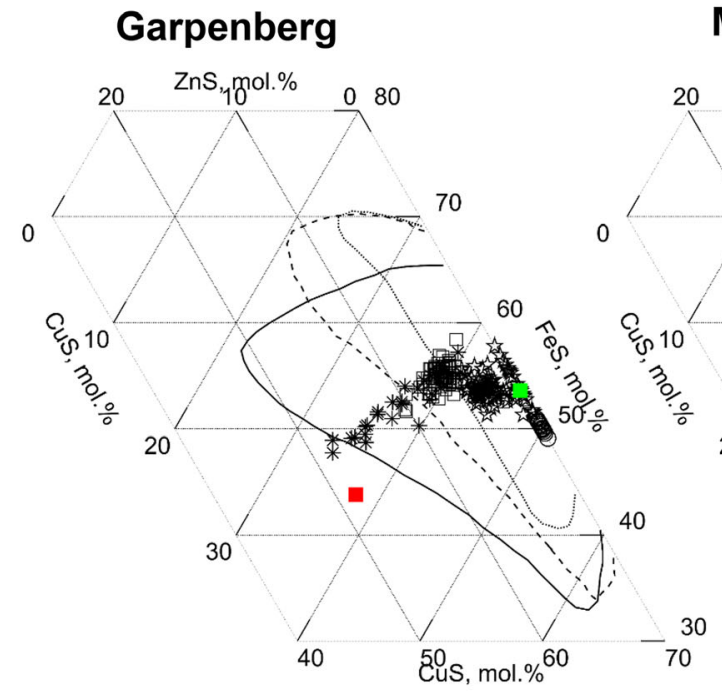

(c)
Maurliden

(b)

zns
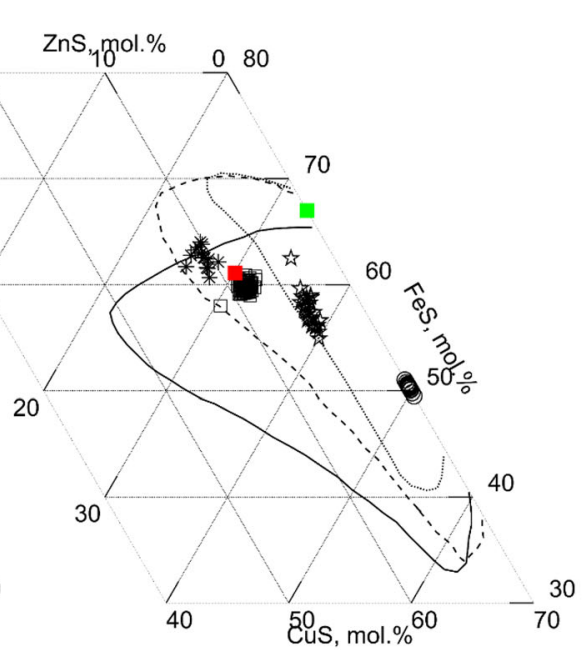

(d)

Fig. 10-Measured compositions of the iss phase (slightly adjusted using Eq. [1]) plotted in the CuS-FeS-ZnS ternary diagram for calcines obtained from isothermal roasting of (a) Rockliden S7574, (b) Rockliden 8232, (c) Garpenberg and (d) Maurliden concentrates. Calculated compositions considering dissolution in $\mathrm{Ccp}$ of all the available $\mathrm{Fe}$, and all the available $\mathrm{Fe}+\mathrm{Zn}$ are shown as green and red squares respectively. Inset presented in Figure 7. Data of phase boundaries from Kojima et al. ${ }^{[20]}$

to other minerals). Notably, this high As + Sb-bearing partially melted Gn solidifies into a single phase unlike the general polymetallic sulphide melts.

The two-phase intergrowths in Rockliden 8232 and Garpenberg calcines (Figures 11(b) and (c), respectively) are found to be compositionally close to a Gn-Ttr pseudobinary system (Spot 1 composition is close to the theoretical $\mathrm{PbS}$, which has $50 \mathrm{~mol}$ pct $\mathrm{Pb}, 50 \mathrm{~mol}$ pct $\mathrm{S}$; Spot 2 composition is close to $(\mathrm{Cu}, \mathrm{Ag}, \mathrm{Fe}, \mathrm{Zn})_{12}(\mathrm{~S}-$ $\mathrm{b}, \mathrm{As})_{4} \mathrm{~S}_{13}$, which stoichiometrically has $41.4 \mathrm{~mol} \mathrm{pct}$ $\mathrm{Cu}+\mathrm{Ag}+\mathrm{Fe}+\mathrm{Zn}, 13.8 \mathrm{~mol}$ pct $\mathrm{Sb}+\mathrm{As}, 44.8 \mathrm{~mol}$ pct $\mathrm{S})$. There are additional elements such as $\mathrm{Sb}, \mathrm{Cu}$ and $\mathrm{Ag}$ dissolved in the $\mathrm{Gn}$ melt fraction. A thermodynamic explanation for this intergrowth formation can be found in the work of Pruseth et al. ${ }^{[24]}$ They studied the high-temperature-phase relations in a $\mathrm{PbS}-\mathrm{Cu}_{2} \mathrm{~S}_{-} \mathrm{Sb}_{2} \mathrm{~S}_{3}$ ternary system, which included sulfosalts such as bournonite (Bour) and meneghinite (Mene) relevant in the present study (Table IV). This ternary system also included Skn, which is known to be a product of thermal decomposition of tetrahedrite $\left(\mathrm{Cu}_{12} \mathrm{Sb}_{4} \mathrm{~S}_{13}\right)$ between $520^{\circ} \mathrm{C}$ and $530{ }^{\circ} \mathrm{C}^{[29,30]}$ that congruently melts at $607.5{ }^{\circ} \mathrm{C} \pm 3{ }^{\circ} \mathrm{C} .{ }^{[29,31]}$ In the $\mathrm{PbS}-\mathrm{Cu}_{2} \mathrm{~S}_{-} \mathrm{Sb}_{2} \mathrm{~S}_{3}$ ternary diagram shown in Figure 12 for $500{ }^{\circ} \mathrm{C}$, the Sb-rich extreme of the $\mathrm{Cu}$-rich melt (point $\mathrm{P}$ ) is almost collinear with the $\mathrm{PbS}-\mathrm{Cu}_{3} \mathrm{SbS}_{3}$ join. Consequently, Gn and Skn (originally $\mathrm{Ttr}$ ) should form a eutectic melt very close to $500{ }^{\circ} \mathrm{C}$. 

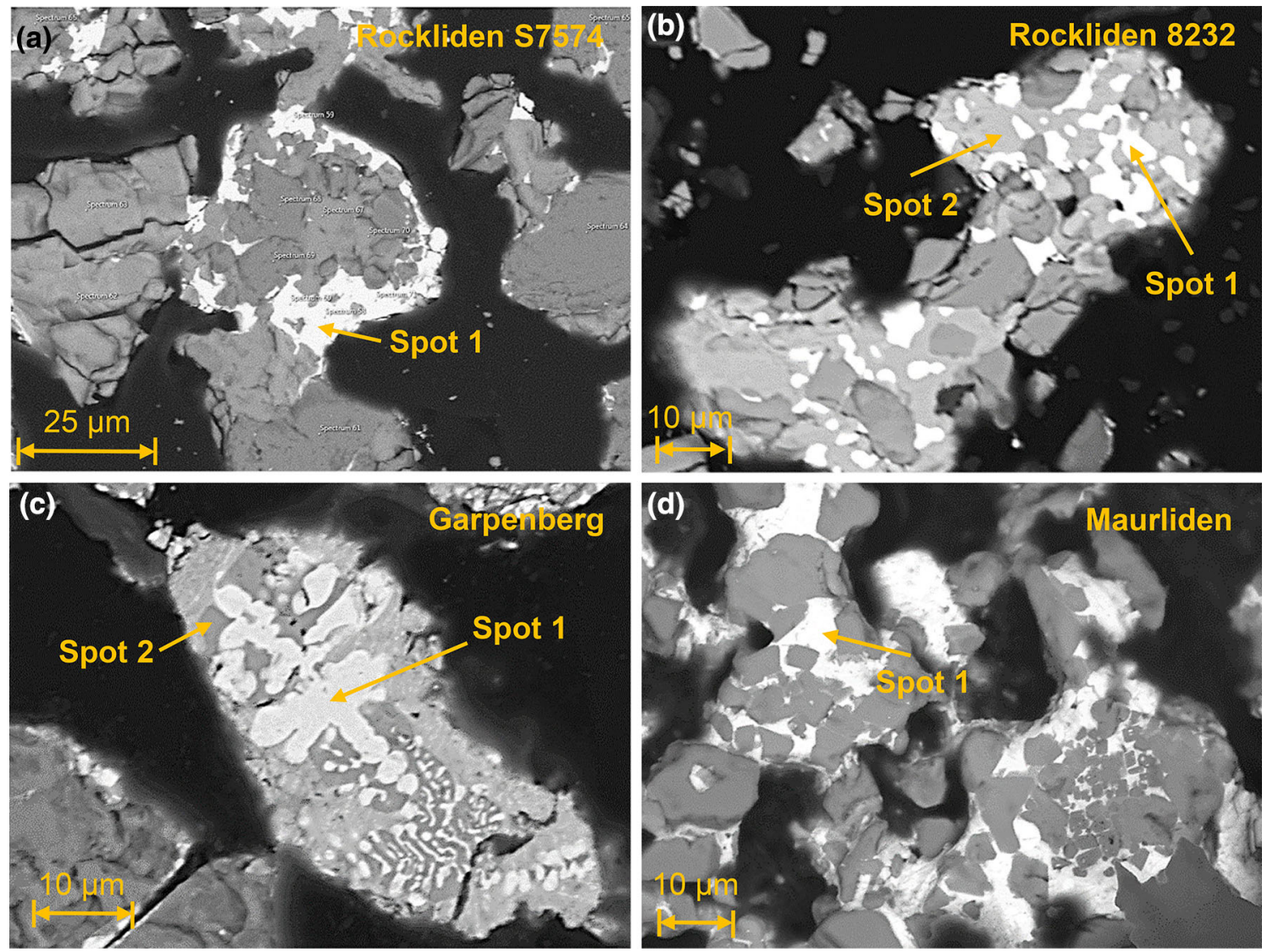

Fig. 11-BSE images of textures representing melt formation in calcines obtained by isothermal roasting at $500{ }^{\circ} \mathrm{C}$ of $(a)$ Rockliden S7574, $(b)$ Rockliden 8232, (c) Garpenberg and (d) Maurliden concentrates. Spots in regions of single phase with area $\geq 25 \mu \mathrm{m}^{2}$ were selected for EDS measurements, located at the tip of the arrows shown in each image.

Table V. Elemental Composition of Liquid-Forming Phases at $500{ }^{\circ} \mathrm{C}$ Determined by EDS Measurements at Spots Indicated in Fig. 11

\begin{tabular}{|c|c|c|c|c|c|c|}
\hline \multirow[b]{2}{*}{ Concentrate/Element (Mol Pct) } & \multirow{2}{*}{$\begin{array}{c}\text { Rockliden S7574 } \\
\text { Spot } 1\end{array}$} & \multicolumn{2}{|c|}{ Rockliden 8232} & \multicolumn{2}{|c|}{ Garpenberg } & \multirow{2}{*}{$\begin{array}{l}\text { Maurliden } \\
\text { Spot } 1\end{array}$} \\
\hline & & Spot 1 & Spot 2 & Spot 1 & Spot 2 & \\
\hline $\mathrm{Pb}$ & 32 & 40.5 & 0 & 39.9 & 1 & 31.9 \\
\hline S & 50.9 & 45.8 & 43.6 & 45.4 & 44.2 & 49.9 \\
\hline As & 5.7 & 0 & 4.3 & 0 & 2.8 & 6.2 \\
\hline $\mathrm{Sb}$ & 7.7 & 2.8 & 9.5 & 3.9 & 10.6 & 7.7 \\
\hline $\mathrm{Fe}$ & 3.6 & 2 & 4.7 & 0 & 6.5 & 2.5 \\
\hline $\mathrm{Cu}$ & 1.2 & 7.4 & 32.4 & 2.7 & 28.3 & 1.7 \\
\hline $\mathrm{Zn}$ & 0 & 1.8 & 3.4 & 0 & 0 & 0 \\
\hline $\mathrm{Ag}$ & 0 & 0 & 2.2 & 8.2 & 6.6 & 0 \\
\hline $\mathrm{Cu}+\mathrm{Ag}+\mathrm{Fe}+\mathrm{Zn}$ & 4.8 & 11.2 & 42.7 & 10.9 & 41.4 & 4.2 \\
\hline $\mathrm{Sb}+\mathrm{As}$ & 13.4 & 2.8 & 13.8 & 3.9 & 13.4 & 13.9 \\
\hline $\mathrm{Pb}+\mathrm{As}+\mathrm{Sb}+\mathrm{Fe}+\mathrm{Cu}+\mathrm{Zn}+\mathrm{Ag}$ & 50.2 & 54.5 & 56.5 & 54.7 & 55.8 & 50 \\
\hline
\end{tabular}

Above compositions are average of 5 EDS measurements at the same corresponding spot.

Considering the compositional similarity of Skn to $\mathrm{Cu}_{12} \mathrm{Sb}_{4} \mathrm{~S}_{13}$ and the expected lowering of the melt formation temperature due to the presence of additional elements such as $\mathrm{Ag}, \mathrm{As}, \mathrm{Fe}$ and $\mathrm{Zn}$ in $\mathrm{Ttr}$, the two-phase intergrowths in Rockliden 8232 and Garpenberg calcines apparently correspond to a eutectic melt formation on the Gn-Skn join near $500{ }^{\circ} \mathrm{C}$. 


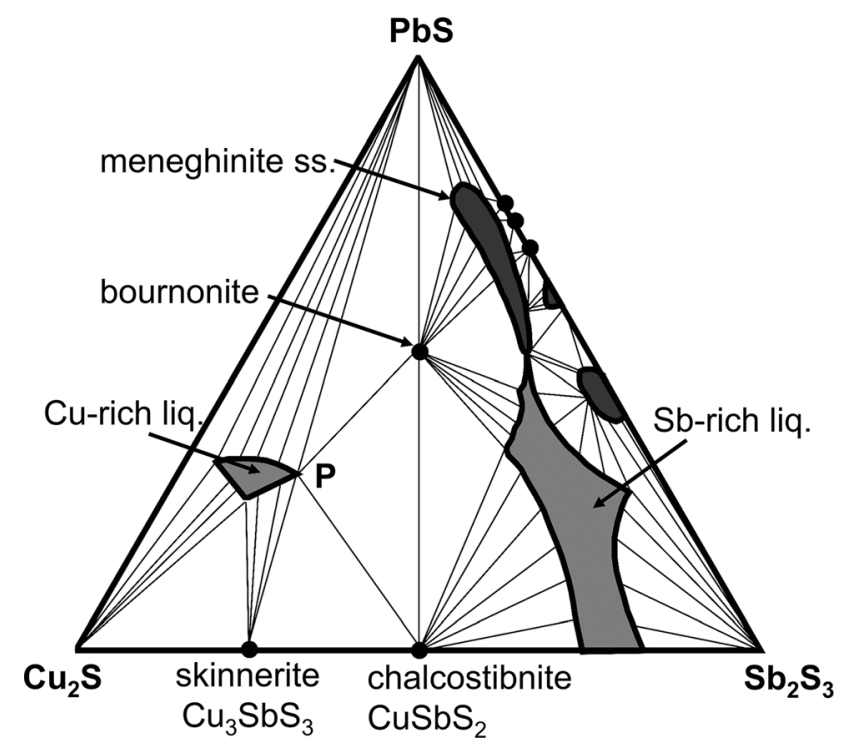

Fig. $12-\mathrm{Cu}_{2} \mathrm{~S}-\mathrm{PbS}-\mathrm{Sb}_{2} \mathrm{~S}_{3}$ phase diagram at $500{ }^{\circ} \mathrm{C}$. Data from Frost et al. ${ }^{[17]}$ and Pruseth et al. ${ }^{[2]}$

Pruseth et al. ${ }^{[24]}$ also reported the involvement of another sulfosalt mineral, Bour, in causing early melt formation. They found that an assemblage of Gn + Skn + Bour started to form the $\mathrm{Cu}$-rich melt phase at $459{ }^{\circ} \mathrm{C} \pm 1{ }^{\circ} \mathrm{C}$. Therefore, the presence of other sulfosalts such as Bour and Mene in the four concentrates (Table IV) in addition to Ttr further augments their early melt formation tendencies.

Therefore, concentrates having $\mathrm{Gn}+$ Sb-sulphosalts but missing Asy will likely form a melt phase that solidifies into a two-phase intergrowth.

\section{Enlargement of liquid phase during non-isothermal} roasting

Figure 13(a) presents a macroscopic image of a sintered calcine obtained from non-isothermal roasting of Garpenberg concentrate up to $700{ }^{\circ} \mathrm{C}$. In this case, the concentrate was subjected to slow heating and slow cooling, unlike during the isothermal roasting. It is evident that several nuggets of solidified melt are trapped in this sintered calcine. Notably, as presented earlier for the Garpenberg concentrate, only one such nugget was visible in the sintered calcine obtained by isothermal roasting at $700{ }^{\circ} \mathrm{C}$ (Figure 3). Clearly, the non-isothermal run resulted in an increase in the quantity of melt generation. A microstructure (BSE image) of the sintered calcine together with an entrapped nugget is presented in Figure 13(b).

There are two distinct intergrowth textures (one relatively coarser than the other) in the microstructure of the solidified nuggets, most clearly shown in the BSE image in Figure 13(c). This suggests the formation of two distinct sulphide melts. The phase that appears bright in the BSE image is common in both textures. Table VI lists the composition of the contributing phases, measured at the locations indicated in Figure 13(c). (a)
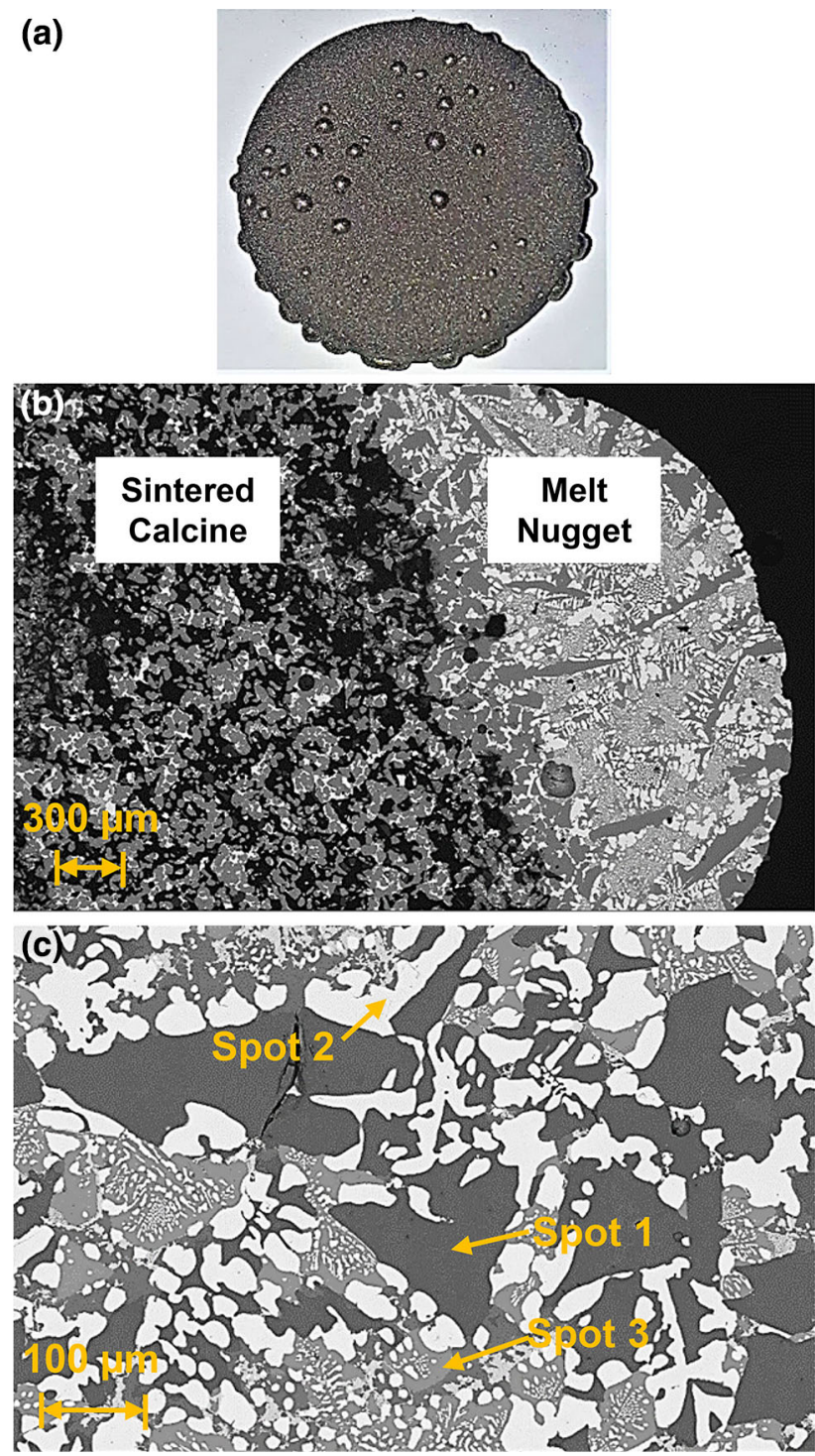

Fig. 13-Calcine from non-isothermal roasting of Garpenberg concentrate up to $700{ }^{\circ} \mathrm{C}$. (a) Macroscopic image showing the solidified melt nuggets trapped in the sintered calcine; $(b)$ BSE image showing the microstructure of sintered calcine and a nugget of solidified melt; $(c)$ BSE image of solidified melt nugget with locations of EDS spot measurements shown as the tip of the arrows.

The composition of the phase constituting the fine intergrowth, measured at Spot 3 in Figure 13(c), matches closely with the theoretical stoichiometry of Ttr-41.4 mol pct $\mathrm{Cu}+\mathrm{Ag}+\mathrm{Fe}+\mathrm{Zn}, 13.8$ mol pct Sb + As and $44.8 \mathrm{~mol}$ pet S. Similarly, the phase in the coarse intergrowth, measured at Spot 1, corresponds to the iss phase of the $\mathrm{Cu}-\mathrm{Zn}-\mathrm{Fe}-\mathrm{S}$ system presented in Section III-C -3 of this article. Also, the common bright phase has a composition similar to Gn (measured at Spot 2).

Therefore, the two liquid phases coexisting at $700{ }^{\circ} \mathrm{C}$ in the calcine are: (1) a low-melting phase belonging to the Gn-Ttr join appearing as the fine intergrowth; (2) a low-melting phase belonging to the $\mathrm{Gn}$-iss join appearing as the coarse intergrowth. Here again, similar to the findings from the isothermal experiments, $\mathrm{Gn}$ is found 
Table VI. Elemental Composition of Phases Contributing to Liquid Formation During Non-isothermal Roasting of Garpenberg Concentrate up to $700{ }^{\circ} \mathrm{C}$ Determined by EDS Measurements at Spots Indicated in Fig. 13(c)

\begin{tabular}{lrrr}
\hline & \multicolumn{3}{c}{ Garpenberg } \\
\cline { 2 - 4 } Concentrate/Element (Mol Pct) & Spot 1 & Spot 2 & Spot 3 \\
\hline $\mathrm{Pb}$ & 0.0 & 48.4 & 0.0 \\
$\mathrm{~S}$ & 49.4 & 49.5 & 44.2 \\
$\mathrm{As}$ & 0.0 & 0.0 & 1.6 \\
$\mathrm{Sb}$ & 0.0 & 0.0 & 12.4 \\
$\mathrm{Fe}$ & 27.4 & 0.0 & 5.2 \\
$\mathrm{Cu}$ & 22.3 & 2.1 & 31.8 \\
$\mathrm{Zn}$ & 1.0 & 0.0 & 1.6 \\
$\mathrm{Ag}$ & 0.0 & 0.0 & 3.2 \\
\hline
\end{tabular}

Above compositions are average of 5 EDS measurements at the same corresponding spot.

to be a common contributor to two different types of low-melting sulphide melts. This is in agreement with the observations made by Frost et al. ${ }^{[17]}$ that the presence of $\mathrm{Gn}$ in a sulphide mineral assemblage lowers the melt formation temperature.

The thermodynamic basis for low-melting phase formation on the Gn-Ttr join has been discussed previously in this article in Section III-C-4. Regarding the coarse intergrowth between $\mathrm{Gn}$ and iss phase, a similar system of $\mathrm{CuFeS}_{2}-\mathrm{PbS}$ was investigated by Craig et al. ${ }^{[22]}$ They stated that melt formation on the $\mathrm{CuFeS}_{2}-\mathrm{PbS}$ join can begin at $630{ }^{\circ} \mathrm{C}$. This has relevance to the present study since the iss phase was found to originate from the transformation of Ccp mineral, as presented in Section III-C-3. Stevens et al., ${ }^{[23]}$ studying another closely related system of Gn-Py-Sph-Ccp assemblage, also observed the initiation of partial melting of sulphides near $700{ }^{\circ} \mathrm{C}$.

\section{CONCLUSIONS}

The following conclusions can be drawn based on the laboratory-scale roasting experiments performed over four different $\mathrm{Cu}$-rich polymetallic concentrates in inert atmosphere:

(1) Two different mechanisms of particle agglomeration lead to sintering: (a) solid-state assimilation of $\mathrm{Cu}$-, $\mathrm{Zn}$ - and Fe-bearing main sulphide minerals such as chalcopyrite, sphalerite and pyrrhotite (originally pyrite) to form a high-temperature solid solution, the iss phase; (b) low-melting liquid phase formation involving partial melting of galena.

(2) Appreciable solid-state assimilation takes place at $500{ }^{\circ} \mathrm{C}$, which is confirmed by the increased $\mathrm{Fe}$ mol pct and $\mathrm{Zn}$ mol pet in the original Ccp grains. The extent of solid-state assimilation increases with a further increase in temperature due to the consequent expansion of the phase boundary of the iss phase towards higher Fe mol pct and $\mathrm{Zn}$ mol pet.
(3) Liquid formation is also appreciable at $500{ }^{\circ} \mathrm{C}$. Partial melting of galena facilitated by the presence of impurity-bearing minerals, mainly the arsenopyrite and Sb-sulphosalts, is mainly responsible for early melt formations.

(4) In concentrates comprising galena + pyrite + arsenopyrite (in addition to other minerals), there is partial melting of galena near $500{ }^{\circ} \mathrm{C}$, and the $\mathrm{Pb}$ is partly substituted by $\mathrm{As}, \mathrm{Sb}, \mathrm{Cu}$ and $\mathrm{Fe}$ in the melt phase. This polymetallic melt solidifies as a single phase unlike the general sulphide melts. Arsenopyrite therefore acts as a melt-forming precursor that can partially melt galena and other Sb sulphosalts to form a single-phase polymetallic melt phase.

(5) In concentrates comprising galena + tetrahedrite (in addition to other minerals, but lacking arsenopyrite), a melt forms near $500{ }^{\circ} \mathrm{C}$, which solidifies as a two-phase intergrowth on fast cooling. The existence of a eutectic on the $\mathrm{PbS}-\mathrm{Cu}_{3} \mathrm{SbS}_{3}$ pseudobinary system near $500{ }^{\circ} \mathrm{C}$ thermodynamically justifies this melt formation.

(6) Apart from the impurity-bearing minerals such as arsenopyrite and $\mathrm{Sb}$ sulphosalts, galena also forms a melt phase $<700{ }^{\circ} \mathrm{C}$ with the iss phase. Prolonged heat exposure during non-isothermal experiments revealed this melt formation possibility. Therefore, the presence of galena generally lowers the melt formation temperature in polymetallic concentrates causing early sintering during roasting in an inert atmosphere.

\section{ACKNOWLEDGMENTS}

Open access funding provided by Lulea University of Technology. The authors thank (1) $\mathrm{CAMM}^{2}$, the Center for Advanced Mining and Metallurgy at Luleå Tekniska Universitet, Sweden, for the financial support, (2) personnel at Boliden $\mathrm{AB}$ for providing concentrate samples and chemical analyses, and (3) the Ore Geology Division at Luleå Tekniska Universitet, Sweden, for providing concentrate samples produced by them through laboratory-scale flotation in a previous study.

\section{OPEN ACCESS}

This article is licensed under a Creative Commons Attribution 4.0 International License, which permits use, sharing, adaptation, distribution and reproduction in any medium or format, as long as you give appropriate credit to the original author(s) and the source, provide a link to the Creative Commons licence, and indicate if changes were made. The images or other third party material in this article are included in the article's Creative Commons licence, unless indicated otherwise in a credit line to the material. If material is not included in the article's Creative Commons licence and your intended use is not permitted by statutory 
regulation or exceeds the permitted use, you will need to obtain permission directly from the copyright holder. To view a copy of this licence, visit http://creativec ommons.org/licenses/by/4.0/.

\section{REFERENCES}

1. P.R. Taylor and T.A.R. Putra: Celebrating the Megascale, Springer, Cham, 2016, pp. 197-211.

2. S. Nakazaw, A. Yazawa, and F.R.A. Jorgensen: Metall. Mater. Trans. B, 1999, vol. 30B (3), pp. 393-401.

3. A. Björnberg, Á Holmström, and G. Lindkvist: US Patent, 4626279, 1986.

4. A Holmstrom: PhD Thesis, Royal Institute of Technology, Dept. of Production Technology (Mining and Steel Industry), 1988.

5. R. Padilla and M.C. Ruiz: Behavior of Arsenic, Antimony and Bismuth at Roasting Temperatures, Springer, Cham, 2016, pp. 43 50.

6. M. Devia, I. Wilkomirsky, and R. Parra: Miner. Metall. Process., 2012, vol. 29 (2), pp. 121-28.

7. W. Lu and Z. Yin: Int. J. Miner. Process., 2016, vol. 153, pp. 1-7.

8. S. Shibuya, C. Tokoro, and T. Okura: EMC, 2013, vol. 2013, pp. 111-22.

9. I. Wilkomirsky, F. Parada, A. Ulloa, A. Carrasso, and L. Jeraldo: Proceedings of the IV International Conference on Clean Technologies for the Mining Industry, Concepción, Concepción University Press, Chile, 1998, pp. 613-21.

10. I. Wilkomirsky, R. Parra, F. Parada, and E. Balladares: COM 2014 - Conference of Metallurgists Proceedings, Canadian Institute of mining, Metallurgy and petroleum, Canada, 2014

11. K. Haga, B. Altansukh, and A. Shibayama: Mater. Trans., 2018, vol. 59 (8), pp. 1396-1403.

12. M. Benlyamani and F. Ajersch: Metall. Trans. B, 1986, vol. 17 (4), pp. $647-56$.

13. T. Coetsee, G. Naudé, J. Richards, A. Walliser, and D. Bessinger: Miner. Process. Extr. Metall., 2013, vol. 122 (2), pp. 122-28.
14. J. Shu, V. Lakshmanan, and J. Convey: Can. Metall. Q., 1999, vol. 38 (4), pp. 215-25.

15. F.E. Minz, N. Bolin, P. Lamberg, K. Bachmann, J. Gutzmer, and C. Wanhainen: Miner. Eng., 2015, vol. 82, pp. 125-35.

16. J. Sandecki and O. Amcoff: Neues Jahrb. Miner. Abh. 1981, vol. 141, Issue 3, pp. 324-40.

17. B.R. Frost, J.A. Mavrogenes, and A.G. Tomkins: Can. Mineral., 2002, vol. 40 (1), pp. 1-18.

18. A.G. Tomkins, D.R. Pattison, and B.R. Frost: J. Pet., 2006, vol. 48 (3), pp. 511-35.

19. T. Lager and E. Forssberg: Trans. Inst. Min. Metall., Sect. C, 1990, vol. 99, pp. 54-61.

20. S. Kojima and A. Sugaki: Mineral. J., 1984, vol. 12 (1), pp. 15-28.

21. S. Kojima and A. Sugaki: Econ. Geol., 1985, vol. 80 (1), pp. 158 71.

22. J. Craig and G. Kullerud: Carnegie Inst. Wash. Yearb., 1967, vol. 65 , pp. $344-52$

23. G. Stevens, S. Prinz, and A. Rozendaal: Econ. Geol., 2005, vol. 100 (4), pp. 781-6.

24. K. Pruseth, B. Mishra, and H. Bernhardt: Econ. Geol., 1997, vol. 92 (6), pp. $720-32$

25. A.G. Tomkins, B.R. Frost, and D.R. Pattison: Can. Mineral., 2006, vol. 44 (5), pp. 1045-62.

26. N.J. Bolin: Boliden Internal Report no. TM REP2010/043, 2010, vol. Boliden Intern. Rep. No. TM_REP2010/043.

27. F. Minz: PhD Thesis, Luleå Tekniska Universitet, Luleå, Sweden, 2016.

28. J. Mavrogenes, I. MacIntosh, and D. Ellis: Econ. Geol., 2001, vol. 96 (1), pp. 205-10.

29. T. Barbier, P. Lemoine, S. Gascoin, O.I. Lebedev, A. Kaltzoglou, P. Vaqueiro, A.V. Powell, R.I. Smith, and E. Guilmeau: J. Alloys Compd., 2015, vol. 634, pp. 253-62.

30. M.H. Braga, J.A. Ferreira, C. Lopes, and L.F. Malheiros: Mater. Sci. Forum, 2008, vols. 587-588, pp. 435-39.

31. B.J. Skinner, F.D. Luce, and E. Makovicky: Econ. Geol., 1972, vol. 67 (7), pp. 924-38.

Publisher's Note Springer Nature remains neutral with regard to jurisdictional claims in published maps and institutional affiliations. 